\title{
Segregation legal and natural: an empirical study of the legally protected and free market housing ownership on the Peak
}

\section{[Text and references: 7182 words]}

\begin{abstract}
The phenomenon of protectionism in land policy has survived in the globalised age for various reasons. This case study on the destruction of racially discriminatory zoning in laissez-faire Colonial Hong Kong shows what could happen when protectionist measures are removed by the government. Approaching the reality of discrimination from Cheung's (1974) economic theory of price controls, Lai \& Yu (2001) argued, on the basis of the records of official speeches and writings and a small sample of post-war assignments for housing lots, that the pre-World War II segregation law was motivated more by economic protectionism in favour of Europeans rather than by any social stigma against non-Europeans or genuine environmental externalities generated by Chinese housing. This paper approaches the same phenomenon from a new perspective and with a better method. It was revealed that natural or contractual, as opposed to legal, agglomeration could happen even under written discriminatory laws that allowed a degree of inclusion for the ethnic group that suffered discrimination. This revelation was based on an examination of the ethnicity of the original owners and subsequent purchasers of all identifiable 627 housing lots on the Peak in Hong Kong for 115 years from 1876 to 1990, as found in the 421 relevant Crown Leases and 1,255 assignments. These housing lots fell into 23 street neighbourhoods and could be classified by altitude. The key findings lend support to the arguments that even if the post-war colonial literature evaded or even distorted the subject, there was no true racial animosity between European and Chinese citizens because the exclusionary laws were driven by economic protectionist motives and the repeal of the laws was socially and economically beneficial for both Chinese and Europeans.
\end{abstract}

Keywords: racial segregation; agglomeration; Crown Leases; Peak; price control; zoning

\section{INTRODUCTION}

The persistence of racial segregation under free market conditions, likely a consequence of the positive benefits of agglomeration, has been interpreted largely from an economic perspective (Logan et al., 1994; Wheeler, 2001; Chung \& Kalnins, 2001; Rosenthal \& Strange, 2003), and suggests that racially discriminatory laws in the past might well have been propelled not just by racial considerations, but economic ones, too. Whether or not laissez faire could be a viable policy alternative to positive discrimination against a certain ethnic group after such laws were removed has not been given due consideration. This post-colonial case study of Colonial Hong Kong will shed light on this question, as well as on the persistence of protectionist land ownership measures in many countries.

Although ownership in the 'agglomeration' literature has concentrated principally on business ownership rather than on property (see, for instance, Logan et al., 1994), the 
issue of land ownership in segregation research has been looming, as exemplified by the recent work of Burger (2006) in an European Union context and the works of Uyanga (1989), Christopher (1997, 2001), Huchzermeyer (2001), McConnachie \& Shackleton (2010), Firman (2004), and Kalabamu (2006). It is hoped that this Asian case study will provide useful insights and technical references for researchers and policymakers who are engaged in residential planning in a market economy freed from racially discriminatory laws.

To provide further and better evidence for the hypothesis and correcting certain errors in the pioneering work on housing segregation in Colonial Hong Kong by Lai \& Yu (2001), this study on housing agglomeration is original in both theoretical and methodological terms. Theoretically, it reveals an interesting phenomenon of the acquisition and agglomeration of properties by Chinese buyers, notwithstanding the exclusionary zoning that prohibited their residence on such properties, thus providing another real life example of Cheung's theory of price control (1974) that was formally modelled by Lai \& $\mathrm{Yu}$ (2001). In terms of research methodology, as revealed in the literature review, this paper will demonstrate the fruitfulness of using reliable, publicly available, and easily verifiable data found in conveyancing documents viz. Crown Leases and assignments to evaluate the degree of segregation or agglomeration present. Besides these research implications, this work should be a useful reference for policymakers who are determined to eradicate segregation by removing artificial barriers in the land market.

\section{THE HISTORICAL BACKGROUND OF RACIAL SEGREGATION IN HONG KONG}

Colonial Hong Kong, founded in 1842, was world famous for being economically successful under a laissez faire economy governed by the rule of law. However, its land market, based on a near universal leasehold system, was regulated well before the enactment of the Town Planning Ordinance of 1939.

A survey of the post-World War II writings in English by Lai $(2002,2011)$ on Endacott (1964a; Endacott 1964b: 243); Sayer 1975: 128-9; Evans (1971: 26-7); Hopkins (1971); Hughes (1976: 125-6); Miners (1975); Crisswell \& Watson (1982: 63); Pryor (1983); Bristow (1984: 258); Miners (1987: 54-5, 290, 293); Wesley-Smith (1987); Morris (1988: 138-0; 190-1); Birch (1991: 46); Cameron (1991:215); Smith (1993: 132); Welsh (1993: 378-9); Courtauld \& Holdsworth (1997: 46); Morris (1997: 141); Flowerdew (1998: 189); Carroll (1999:14); Wiltshire (1995: 11); Owen \& Roberts (1999: 18); and Wood (2000), but omitting Briggs \& Crisswell (1977); Tsai (1993); Smith (1995); White (1996); Fung (1997); Ting (1997); Wesley-Smith (1998); Munn (2001); and Tsai (2001), revealed that the presence of racially discriminatory zoning laws driven by economic protectionist concerns to favour Europeans was generally either concealed or disguised as a means to keep out the Chinese with undesirable social and housing habits in the literature. These laws evolved in three stages.

\section{The European District Reservation Ordinance}


The first exclusionary zoning law in Hong Kong was the European District Reservation Ordinance of 1888. It prohibited the building of any 'Chinese tenement' within the socalled "European District". It also prohibited the division of residential buildings in the district by more than one person to every one thousand cubic feet of clear internal space. The Ordinance defined a "Chinese tenement" as "any tenement of the type usually designed for habitation by Chinese other than domestic servants". The "European District," defined in Section 2 of the ordinance, referred to a zone in which most hilly residential areas on the Island of Hong Kong were located. It includes the area known as the Mid-Levels. The core of the European or Hill District was the highest mountain on Hong Kong Island, Victoria Peak, or the Peak. The Peak has, since its opening to the general public, been a famous tourist attraction, with excellent views over Hong Kong's Victoria Harbour on a clear day.

\section{Hill District Reservation Ordinance}

The second exclusionary zoning law, the Hill District Reservation Ordinance (Ordinance No. 4 of 1904), gave the Peak a de jure status as a zone that expressly excluded Chinese inhabitants. It was a successor to the European District Reservation Ordinance that had been repealed by the Public Health and Building Ordinance of 1903. The Hill District Reservation Ordinance defined the Hill District as an "area in the Island of Hong Kong situated above the 788-foot contour and to the west of a line drawn in a north and south direction through Middle or Cemetery Gap, including the hills known as Mount Cameron, Mount Gough, Mount Kellett, and Victoria Peak. The Hill District Reservation Ordinance explicitly and unambiguously prohibited the Chinese from residing in the Hill District zone. Section 3 of the ordinance read:

It shall not be lawful (save in accordance with the provisions of this Ordinance) for any owner, lessee, tenant or occupier of any land or building within the Hill District to let such land or building or any part thereof for the purpose of residence by any but non-Chinese or to permit any but non-Chinese to reside on or in such land or building.

The Peak District (Residence) Ordinance

The third and last phase of exclusionary zoning was embodied in the Peak District (Residence) Ordinance of 1918. Sub-section 1 of Section 3 of this ordinance stated:

Subject to the provisions of section 4 of this Ordinance, it shall not be lawful for any person whatsoever to reside within the Peak District without the consent of the Governor in Council.

In 1919, a similar ordinance to restrict the hilly part of Cheung Chau, an island in the New Territories, for consented persons was passed. This was known as the Cheung Chau (Residence) Ordinance (Ordinance No. 14 of 1919). The purpose was for the benefit of 
vacationing British and American missionaries. ${ }^{1}$ Although the Chinese members of the Legislative Council were silent during the reading of the bill for the Peak District (Residence) Ordinance, they objected and voted against the bill for Cheung Chau. Mr. Lau Chu-pak said that he could not believe that "of all people, they could have made such a request - preachers and teacher of equality and fraternity that they are" (Hong Kong Hansard 1919: 63-4). Mr. Fok Ho (known to Chinese people as Mr. Ho Fok), another brother of Sir Robert Ho, was more explicit. He said:

In view of the fact that the war had been won by all races in the Empire I cannot be a party to the passing of this Bill which, in my opinion, is nothing more or less than racial legislation (Hong Kong Hansard 1919: 64).

The general requirement for all to obtain consent was apparently based on physical or town planning considerations, as literal interpretations of the 1918 and 1919 ordinances seemed to suggest. However, Lai \& Yu (2001) took that the intent of the 1917 law was to ensure that no Chinese could purchase property in the European reserves. Their evidence was based on two sources. Note that Governor May was prepared to give his assent to these ordinances because he was surprised that Section 3 of the older law, the Hill District Reservation Ordinance, "did not, in law, prevent a Chinese from acquiring his own house in the district and living in it” (Wesley-Smith 1987: 22). Besides, they were inspired by the Sir Robert Tung Ho saga. Sir Ho (referred to as Robert Ho Tung in materials in the English language and "Mr. Ho Tung" by the Chinese), a Eurasian who was extremely successful in business and held in high regard by the colonial administration, had, by 1917, owned three houses in the Peak District, and his brother, Mr. Kam Tong Ho (known to the Chinese as "Mr. Ho Kam Tong”), had bought another.

The story began when Sir Ho bought a house on the Peak and began to live in it in 1906. A constitutional row occurred in 1908 "when the Chief Justice, Sir Francis Piggott, a tenant of the Eyrie which overlooked the Governor's summer retreat Mountain Lodge, proposed to let the house to Mr. Ho Tung” (Wesley-Smith, 1987: 21). The Governor in Council regarded Ho as Chinese and ignored Sir Piggott's vehement objection to the refusal of the council to grant Ho exemption under Section 4 of the Hill District Reservation Ordinance. The Colonial Government also swiftly re-purchased the property from the younger Ho, who donated his proceeds to charity (Wesley-Smith, 1987). After the sagas of the two Ho's, no Chinese attempted to obtain permission from the Governor in Council to reside in the reserves.

The formation of statutory racial segregation in Hong Kong was due to a desire to create a protected housing market for the European community. Racial prejudice might have factored into this, but economic protectionism was more decisive. Racial zoning is

1 There was no record of attacks by local Chinese on foreign missionaries in Cheung Chau or other parts of Hong Kong. Indeed, missionaries were generally respected for their charity and education endeavours. The local Chinese Christian population (Catholics and Protestants) has been growing since missionaries came to Hong Kong. 
equivalent to price control, according to Cheung's (1974) theory, and it eventually collapsed such that the lost rent could be recaptured. By the time the first statutory discrimination ordinance was in place in 1888, Colonial Hong Kong was almost half a century old. Furthermore, extremely successful business people in Hong Kong were not limited to Europeans. Many Chinese and Jews from Europe were also highly successful, and, like their European counterparts, some were active in charitable activities. There is no better description of this fact than that stated in Smith's A Sense of History. The following description from a section in Smith's work, entitled "The Gradual Emergence of Substantial Chinese Land Owners,” is informative:

The first Chinese settlers (during the 1840s) did not have the capital to engage in extensive business activities. They did reap a quick profit, however. The Government rewarded their defiance of the orders of the Chinese officials prohibiting Chinese to have dealings with the English. For their willingness to provide the needs of the foreign community, they were granted land. Most of the original holders of the land certificates sold their rights after a few years. Some, however, retained their original allotments and with the capital acquired through business activities bought up the lots of others. It was this group that formed the backbone of the Chinese community in Hong Kong. Their possession of landed property was a symbol of their intention to make Hong Kong their home (Smith, 1995: 47-8; author's brackets).

The removal of such segregation in 1946, according to Lai \& Yu (2001), was also based on economic considerations during an immediate post-war situation in which maintaining the exclusionary law would prevent the now-deprived European landowners from realising their landed properties. The evidence they produced was documentary. Regarding the formation of the laws, one of the sources they relied on was the content of the confidential despatch dated 5 September 1917 from Governor Francis Henry May to a Member of Parliament, the Right Honourable Walter Long. This despatch states the worry among Europeans that the "wealthy Chinese" would buy properties on the Peak at "fancy prices". As for the post-war repeal of the discriminatory laws, Lai \& Yu (2001) adduced a sample of the records of the assignment of European land parcels in the Peak area to Chinese persons or companies after the applicable law was repealed in 1946.

\section{THREE RESEARCH QUESTIONS}

In light of the above discussion, three research questions that can be posed to Lai \& Yu (2001) remain unanswered.

\section{Research Question 1: Did Ho Tung live on the Peak before 1946?}

Cheung's (1974) theory of price control, if validly applied, should call for an examination of the existence of a black market and, hence, a large number of Chinese residing on the Peak, even if they did not own land at all. While this empirical question in itself is worthy of investigation and should be the subject of a separate inquiry, there is an even greater need to verify their supposition, based on the saga of Sir Robert Ho Tung, that the 
Chinese were effectively prevented from owning land, not to mention living, on the Peak under the third piece of legislation. Thus, our first research question is a historical one: did Sir Ho Tung actually reside on the Peak during the operation of the racially discriminatory system?

Lai \& Yu (2001) did not investigate if a black market really existed, which was entailed by Cheung's theory on the Peak. The question is highly complicated, and it is understandable why an initial study avoided it. For one thing, the factual absence of any Chinese from the Peak would imply that there was no black market. However, the law permitted Chinese to live there as domestic servants. Thus, any evidence of the existence of Chinese residents on the Peak is insufficient to prove the existence of a black market. Official census statistics would not be useful unless they distinguish between real and "pretend" servants. Here, the need to comprehensively investigate the history of ownership of land parcels on the Peak, which Lai \& Yu (2001) did not do, is imperative.

The very fact that the European reserves had retreated uphill (the Mid-Levels were abandoned in 1904 for the ultimate enclave above the 788-foot contour, at which the Peak stands) is a significant reflection of the economic status of the Chinese. This retreat might well have meant that the economic pressures for yielding such land parcels, including all those above the 600-foot contour previously protected by the European District Reservation Ordinance and the European District Reservation (Amendment) Ordinance of 1888, to the "infiltrating" Chinese were irresistible. However, the validity of the economic model of Lai \& Yu (2001), however interesting, was predicated on a few pre-war archive materials and a sample of post-war land titles.

\section{Research Question 2: Did Chinese ever buy land on the Peak before 1946?}

The question about Sir Ho, which could be purely a matter of law enforcement, is far less significant than the question of whether or not any Chinese bought land on the Peak when the Peak District (Residence) Ordinance was in force. Based on the saga of Mr. Ho Kam Tong, Lai \& Yu seemed to suggest that no Chinese could buy land after the last zoning law was enacted. This law, in fact, only forbade the Chinese from living on the Peak in their own right, but did not stop them from living there as servants or becoming owners. To reiterate, while this ordinance rendered Chinese residence on the Peak lawful only with the permission of the Governor in Council, it did not stop or disallow the Chinese from buying or owning land there. In fact, Chinese land buyers could obtain incomplete private property rights: full freedom of alienation and income, but limited freedom of use.

Back to Cheung's theory, one logical way to corroborate the idea that the Peak zoning law was a form of price control would be to establish that both the percentage of all land parcels owned by Chinese and the percentage of new land parcels released by the government to the Chinese declined after the introduction of the 1918 law because these factors lend support to the argument that the zoning law attenuated the private property rights of land. 
If it happened that either type of percentage was rather stable or, in fact, increased, then our beliefs in the comfortable theory of price control would be shattered because the law did not cause a fall in the desire of the Chinese to hold onto old land or acquire new land on the Peak, notwithstanding the legal constraint that they could not reside anywhere in their own land.

Research Question 3: When and how did the Chinese establish themselves on the Peak after 1946?

Did (and when) the Chinese actually 'capture' the Peak after the exclusionary law, or segregation by edict, was repealed? This surely involved the dimension of speed, which Lai \& Yu (2001) presumed to be very quick. Lai \& Yu (2001) examined the title documents of only a sample of land parcels for three years.

Besides the question of if or when the Peak was captured by the Chinese as the majority landowner, how exactly did such a capture manifest itself in spatial terms over time?

Granted that the Chinese eventually became the dominant nationality in terms of land ownership on the Peak, this question would pertain to the concept of natural segregation as agglomeration, which this paper has considered. Census statistics in many countries affirmed that migrant populations, which tend to share the same culture and social networks, tend to settle in clusters and colonise certain parts of cities for mutual benefit. This often happens when one street in a neighbourhood becomes "colonised" and then spills over to adjacent streets. While this may not have any discriminatory intent, this does have the effect of segregation, which may be said to be natural or contractual, as no compulsion is involved in the departure of the original inhabitants. Therefore, it is better to call such segregation an agglomeration.

\section{HYPOTHESES, METHODOLOGY, AND DATA}

\section{Hypotheses}

Three empirical hypotheses were established to evaluate the three research questions discussed above. They were:

(Hypothesis 1) Sir Ho Tung had to leave the Peak when the third piece of legislation was in force.

(Hypothesis 2) Agglomeration of the Chinese on the Peak occurred irrespective of the existence of exclusionary zoning law during the study period. 
(Hypothesis 3) Agglomeration of the Chinese on the Peak occurred street by street in an uphill direction to the Peak after the repeal of the exclusionary zoning law during the study period.

Hypothesis 1 addresses Research Question 1, Hypothesis 2 addresses Question 3, and Hypothesis 3 addresses Question 2.

Hypothesis 2 was derived from the basis of Cheung's theory of price control, which predicts that rational economic agents will try their best to bypass regulations or adjust their behaviour in those dimensions of private property that are not regulated.

Hypothesis 3 was based on the assumptions that property values on the Peak would increase with altitude and that the Chinese tend to buy the cheaper lots before acquiring those of greater value. For purposes of evaluation, when $50 \%$ or more of the lots were concentrated in the hands of Chinese owners, we can say that agglomeration was dominant. This simple majority measurement may seem simplistic or even arbitrary, but since we used it as a reference to compare changes in the ratios of ownership throughout history, a holistic picture can be grasped.

These hypotheses should be viewed in light of the fact that land ownership is a significant factor, if not a theoretical issue in segregation research, as evidenced by the work of Uyanga (1989) in a Nigerian; Christopher (1997, 2001); Huchzermeyer (2001) and McConnachie \& Shackleton (2010) in a South African; Firman (2004) in an Indonesian; and Kalabamu (2006) in a Botswanan context. These studies generally confirmed that the removal of segregation laws per se may not lead to the disappearance of racial segregation due to various non-price rigidities or structural conditions that constrain the land market. In contrast, the economy of Colonial Hong Kong was a wellknown laissez faire regime, and thus, its land market should have been much more flexible and less susceptible to non-economic considerations. Whether or not this speculation is valid is an empirical question.

\section{Methodology and data}

To evaluate these questions, we purchased from the Land Registry of Hong Kong the Crown Leases and assignments of all identifiable housing lots for all 23 streets on the Peak. They are generally located at different altitudes and their leases were those executed in the period from the first date of land allocation on each street until 1990. The end year was selected on the consideration that since 1991, there has been a drive to convert land use for houses into one for apartments with multiple ownership, which rendered comparisons more complicated and costly.

The data set consists of the title documents of 627 housing lots on the Peak for 115 years from 1876 to 1990, as found in 421 relevant Crown Leases and 1,255 assignments. These housing lots were located in 23 neighbourhoods. The use of land title data in the segregation research can be traced to the work of Bailey (1966) and Lapham (1971).

\section{Findings and interpretation}


For the lowest street on the Peak, the name and ethnicity of the owner of the plot of land with the smallest lot number were recorded each year from the year the land was first granted until 1990. The process was repeated for the land lot with a greater lot number until we collected the data for all the housing lots along a street. Then, we collected data for the next higher street until a picture of the entire Peak area materialized.

We presented the data collected graphically in Figures 1 and 2 with the names of the land owners suppressed, as they were irrelevant for our analysis. A summary of the findings is provided in Table 1, which shows the year in which the Chinese became the majority owners on the Peak by street in a descending order of altitude.

\section{Table 1 and Figures 1 to 2 near here}

One finding was that contrary to popular belief, the purchase of land by the Chinese occurred under the exclusionary law. Indeed, Figures 1 and 2 demonstrate that land ownership by the Chinese relative to Europeans did not systematically fall with time and even witnessed increases in certain years (say 1931 and 1940). One possible explanation for this was, in line with Cheung's theory, modified to take into account uncertainty over Chinese owners' anticipation of the eventual removal of the zoning law. Another possible reason can be found in the shadow of the Coase Theorem: Chinese owners were content to lease their properties to Europeans, which was just as good, in terms of economics, for their own use. The third possible reason is that leasing properties to Europeans could actually enhance land values, and hence, Chinese buyers voluntarily subjected themselves to statutory restrictions on property rights in the hope of deriving higher rental incomes from purely European neighbourhoods. This possibility is, according to a careful reading of the analysis of Lorne (2009), possibly a path towards sustainable development. A negative right, like a piece of "negative heritage” (Meskell, 2002) judged normatively from a human rights perspective, could bring about economic gain by way of a positive consumption externality due to an agglomeration of Europeans. One obvious externality is their contribution to English landscaping and gardening the land (Home, 1997). We do not advocate racial segregation, but speculate on the possibility of transforming an adverse constraint on property rights into gains through a lease.

In was in this interesting context that Sir Ho Tung owned land on the Peak. Was Sir Robert Ho forced to leave the Peak? While Miners (1987: 293) said he resided elsewhere, Courtauld and Holdsworth (1997: 46) stated otherwise. In any event, Sir Ho was Eurasian and not fully Chinese. A veteran, Charles Barman, a Quartermaster Sergeant in the Hong Kong/Singapore Royal Artillery, recalled that during the Battle of Hong Kong, Sir Robert's residence was used as an artillery headquarters. Barman commandeered the "residence of Sir Robert Ho Tung” near Magazine Gap Bridge (Barman 2009: 11) in the 'Peak District' (p.3) and used it as the "West Administrative Pool" for the artillery of the defenders on 9 December 1941. This meant that Hypothesis 1 was refuted. 
Second, before World War II, under three successive protectionist exclusionary ordinances that discriminated against the Chinese, signs of agglomeration occurred, but only on two Mid-Level (Peel Rise and Lugard Road), not the uppermost, streets in the Peak area. This meant that Hypothesis 2 was not refuted.

Third, after 1946, when the last exclusionary zoning ordinance was repealed, Chinese buyers eventually succeeded in securing properties on the upper levels of the Peak beginning with a property on Mount Austin Road, 540 metres above sea level, in 1959. Most of the agglomeration occurred during the 1970s on streets located 300 to 400 metres above sea level. However, many streets at different altitudes remained in the hands of Europeans until the end of the study period. Therefore, Hypothesis 3 was refuted. Given the fact that the European population of Hong Kong has always been a minority, our findings affirmed that the Peak was, racially speaking, a European colony under free market conditions. Natural segregation or segregation by a spontaneous market did occur during our study period.

During the course of our data interpretation, something appeared to be far more theoretically interesting than the two hypotheses. First, we found that lots falling into the hands of Chinese buyers could be purchased by Europeans and vice versa before and after the repeal of the exclusionary law. Second, there was a general increase in both the number of Chinese and European owners on the Peak after the repeal of the discriminatory law. These facts dispelled speculation that there was any stigmatisation or sterilisation of land by any ethnic group or real animosity between Chinese and Europeans.

\section{CONCLUSION}

The specific factual findings of this case study were that: (a) before World War II, under three successive protectionist exclusionary ordinances that discriminated against the Chinese, the Chinese could only occupy the Mid-Levels, but not the uppermost, streets in the Peak area; (b) after 1946, when the last ordinance was repealed, the Chinese succeeded in eventually capturing the upper levels of the Peak; (c) contrary to popular belief, purchases of land by Chinese buyers happened even under the exclusionary law and there was evidence that their land holdings increased, rather than decreased, even if they could not enjoy their private property rights fully; (d) housing lots falling into the hands of Chinese buyers could be purchased by Europeans and vice versa before and after the repeal of the exclusionary law; (e) there was a general increase in the number of Chinese and European owners on the Peak after the repeal of the discriminatory law and (f) the colonisation of the Peak by the Chinese as residents after 1946 has been slow and the Peak remained a largely European settlement until recently. These findings support the arguments that whether the post-war colonial literature evaded or even distorted the subject, there was no true racial animosity because the exclusionary laws were driven by economic protectionist motives and the repeal of the law was socially and economically beneficial for both Chinese and Europeans.

The above analysis suggested that the freedom of contract is conducive to the preservation of a good housing environment. Could there be an alternative explanation? 
Was it possible that the post-war domination of the Peak by European residents was a legacy of the zoning laws? Arguably, some "rigidities" or customs of land use could have been nurtured by the law, and they could have remained significant by retaining its European social composition. This echoed the argument mooted in the paper that even the pre-war Chinese purchase of land lots could have been driven by a desire to rent to European families to foster a certain quality of housing. This submission can be buttressed by the observations that land lots re-sold by Europeans were typically held only for a relatively short period of time by the Chinese in the interim. However, this argument runs into difficulties, as leasing to Europeans could achieve the same purpose and there is no need for zoning control in their favour. Besides, it is certain that the Peak Club, once the centre of social life on the Peak, went into liquidation and ceased operation on 24.10.1951, and without further investigation into the sociology of the socalled "Peakites"(European residents on the Peak), this alternative explanation remains more speculative and less persuasive than the quantifiable free market argument.

As for the method of evaluating segregation, this paper is an original attempt to use changes in the ownership of land classified by altitude, as indicated by information in land title documents, to evaluate the extent of residential segregation and agglomeration in Hong Kong. In terms of theory, it added to the literature on the economic conditions and institutional aspects of segregation when informed by Cheung's theory of price control. While there is truism in Myrdal's (1944) thesis on discrimination (i.e., it is too complicated to generalise racial matters), and many recent studies (for instance, K'Akumu \& Olima 2007) confirmed this view, our study of the changes in ownership of land parcels on the Peak revealed facts that support an economic interpretation of segregation zoning in Hong Kong.

In theoretical terms, this work qualifies the initial exploration of racially discriminatory zoning by Lai \& Yu (2001) using Cheung's (1974) theory of price control by addressing the issue of the black market and reinterpreting Cheung's theory from the points of view of the Coase Theorem and sustainability (Lai \& Hung 2008). Although the Chinese were not allowed to reside in the zone, they were nevertheless permitted to own land there, and they bought quite a number of properties even before the repeal of the law. This study found an increase in the population of both Chinese and European landowners, which testifies to the argument suggested by Logan et al. (1994); Wheeler (2001); Chung \& Kalnins (2001); and Rosenthal \& Strange (2003) that racially discriminatory laws in the past might not really be founded on the basis of racial considerations alone. It is informative for policymakers as well. The Hong Kong study implies that laissez faire is a workable policy alternative to positive discrimination against a certain ethnic group when it comes to housing supply, as a free market could perform the same role as zoning to enhance the housing environment.

\section{ACKNOWLEDGEMENTS}

The authors acknowledge the useful comments on the manuscript of this paper by an anonymous referee who drew his attention to the recent work of Lorne (2009) and the 
funding support of a Hong Kong Special Administrative Region Government grant no. RGC Ref. No. 713208 


\section{REFERENCES}

Bailey, M.J. (1966), "Effects of race and of other demographic factors on the values of single-family homes.” Land Economics, 42(2), 215-20.

Barman, C. (2009), Resist to the End: Hong Kong, 1941-1945, Hong Kong University Press, Hong Kong.

Birch, A. (1991), Hong Kong: the Colony that Never Was. Guidebook Company, Hong Kong.

Briggs, T. \& Crisswell, C. (1977), The Vanishing City, South China Morning Post, Hong Kong.

Bristow, R. (1984), Land-use Planning in Hong Kong: History, Policies and Procedures, Oxford University Press, Hong Kong.

Burger, A. (2006), "Why is the issue of land ownership still of major concern in East Central European (ECE) transitional countries and particularly in Hungary?" Land Use Policy, 23(4), 571-79.

Cameron, N. (1991), An Illustrated History of Hong Kong, Oxford University Press, New York.

Caroll, J.M. (1999), Chinese collaboration in the making of British Hong Kong. in Ngo, T-W. (Ed.), Hong Kong's History: State and Society under Colonial Rule, Routledge, London, pp. 13-29.

Cheung, S.N.S. (1974), "A theory of price control." Journal of Law and Economics, 17(1), 53-71.

Christopher, A.J. (1997), "Racial land zoning in urban South Africa," Land Use Policy, 14(3), 311-23.

. (2001), "Urban segregation in post-apartheid South Africa." Urban Studies, 38(3), 449-66.

Chung, W. \& Kalnins, A. (2001), "Agglomeration effects and performance: a test of the Texas lodging industry.” Strategic Management Journal, 22(10), 969-8.

Goase, R.H. (1937), "The nature of the firm." Economica, 4(16), 386-405.

Courtauld, C. and Holdsworth, M. (1997), The Hong Kong Story. Oxford University Press, Oxford.

Cowgill, D.O. and Cowgill, M.S. (1951), "An index of segregation based on block statistics." American Sociological Review, 16(6), 825-31. 
Criswell, C. and Watson, M. (1982), The Royal Hong Kong Police (1841-1945), MacMillan, Hong Kong.

Endacott, G.B. (1964a), Government and People in Hong Kong 1841-1962, Hong Kong University Press, Hong Kong.

. (1964b, 1982) A History of Hong Kong, $2^{\text {nd }}$ ed., sixth impression, Oxford University Press, Hong Kong.

Evans, D.M.E. (1971), "Some legal aspects of urbanisation in Hong Kong”, In D.J. Dwyer ed. Asian Urbanisation: a Hong Kong Casebook., Hong Kong University Press, Hong Kong, 20-32.

Firman, T. (2004), "New town development in Jakarta Metropolitan Region: a perspective of spatial segregation.” Habitat International, 28(3), 349-68.

Flowerdew, J. (1998), The Final Years of British Hong Kong: The Discourse of Colonial Withdrawal, Macmillan, London.

Fung, B.Y. (1997), Hong Kong Chinese Capitalists: 1841-1997, Joint Publishing, Hong Kong.

Government of Hong Kong. (1947), Annual Report on Hong Kong for the Year 1946, Local Printing Press, Hong Kong.

Hacker, A. (1997), The Hong Kong Visitors Book: a Historical Who's Who, Odyssey Publieation, Hong Kong.

Han, Z. (2000) Office Decentralisation: an Empirical Study of Hong Kong. Unpublished Ph.D thesis, Department of Surveying, University of Hong Kong.

Han, Z., Lai, L.W.C. and Fan, J.C.S. (2002), "The ornamental fish retail market in Hong Kong: its evolution and evaluation", paper presented to the World Aquaculture Society Conference 2002 held on 23-27 April, 2002 at the Beijing Convention Eentre, China; Aquaculture Economics and Management, 6(Issue.3-4), 231-47.

Harris, D.R. (1999), “Property values drop when blacks move in, because...': racial and socioeconomic determinants of neighborhood desirability." American Sociological Review, 64(3), 461-79.

Home, R. (1997), Of Planting and Planning: The Making of British Colonial Histories, Spon, London. 
Hong Kong Government. (1946), Hong Kong Hansard Session 1946, South China Morning Post, Ltd., Hong Kong.

Hong Kong Government (1919), Hong Kong Hansard Session 1919, Hong Kong Legislative Council official report of proceedings, Legislative Council, Hong Kong.

Hong Kong Telephone Co., Ltd. (1946), Telephone Directory for Hong Kong \& Kowloon, Hong Kong.

Kowloon, Hong Kong.

(1947), Telephone Directory for Hong Kong \&

. (1949), Telephone Directory for Hong Kong \&

Kowloon, Hong Kong.

Hopkins, K. (1971 ed.), Hong Kong: The Industrial Colony: a Political, Social and Economic Survey, Oxford University Press, Hong Kong.

Hughes, R. (1968, 1976), Borrowed Place Borrowed Time: Hong Kong and its Many Faces, Andre Deutsch, London.

Huchzermeyer, M. (2001), "Housing for the poor? Negotiated housing policy in South Africa,” Habitat International, 25(3), 303-31.

Jenner, W.J.F. (1994), The Tyranny of History: The Roots of China's Crisis, Penguin Books, London.

K’Akumu, O.A. \& Olima, W.H.A. (2007), “The dynamics and implications of residential segregation in Nairobi.” Habitat International, 31(1), 87-99.

Kalabamnu, K. (2006), “Patriarchy and women’s land rights in Botswana,” Land Use Policy, 23(3), 237-46.

Keay, J. (1993), The Honourable Company: a History of the English East India Company, HarperCollins, London.

Lai, L.W.C. (1997), "Evaluating office decentralisation”, Australian Land Economics Review, 3(1), 13-24.

- (1998), "The leasehold system as a means of planning by contract: the Hong Kong case," Town Planning Review, (69)3, 245-71.

(1999), "Reflections on the Abercrombie report 1948", Town Planning Review, 70(1), 61-87. 
. (2000), "Housing 'indigenous villagers' in a modern society: an examination of the Hong Kong 'small house' policy”, Third World Planning Review, 22(2), 207-30.

. (2002), "Discriminatory zoning in Colonial Hong Kong: A review of the post-war literature and some further evidence for an economic theory of discrimination," Paper delivered to the session "Land Use, Segregation and Urban Policy" held on 10 July 2002 in the XV World Congress of Sociology, 7 13 July 2002 organised by ISA (International Sociological Association) World Congress, Brisbane, Australia, July 7 to 13, 2002.

(2004), "Spontaneous catallaxis in urban \& rural development under planning by contract in a small open economy: the ideas of Hayek and Mises at work in town \& country planning in Hong Kong," Review of Austrian Economics, $17(2 \& 3), 15586$.

Lai, L. W. C. (2011), "Discriminatory Zoning in Colonial Hong Kong: a Review of the Post-war Literature and Some Further Evidence for an Economic Theory of Discrimination,” Property Management, 29(1), 50-86.

Lai, L.W.C. \& Hung, C.W.Y. (2008), "The Inner Logic of the Coase Theorem and a Coasian Planning Research Agenda," Environment and Planning B: Planning and Design, 35(2), 207-26.

Lai, L.W.C. \& Yu, B.T. (2003), The Power of Demand and Supply: Thinking Tools and Case Studies for Students and Professionals, Hong Kong: Hong Kong University Press.

Lai, L.W.C. \& Yu, M.K.W. (2001), “The rise and fall of discriminatory zoning in Hong Kong”, Environment and Planning B: Planning and Design, 28(2), .295-314.

Lam, Y.L. (1985), Hong Kong History. $4^{\text {th }}$ ed., Shanghai Book Store, Hong Kong.

Lapham, V. (1971), “Do blacks pay more for housing?” The Journal of Political Economy, 79(6), 1244-57.

Logan, J.R., Alba, R.D. and McNulty, T.L. (1994), "Ethnic economies in metropolitan regions: Miami and beyond.” Social Forces, 72(3), 691-724.

Lorne, F.T. (2009), "Macro-entrepreneurship and Sustainable Development: The Need for Innovative Solutions for Promoting Win-win Interactions," Environmental Economics and Policy Studies, 10(2), 69-85.

Marcuse, P. \& Van Kempen, R. (2000), Globalizing Gities: a New Spatial Order, Blackwell, Oxford. 
McCarthy, L. (2002), "The brownfield dual land-use policy challenge: reducing barriers to private redevelopment while connecting reuse to broader community goals." tand Use Policy, 19(4), 28796.

McConnachie, M.M. \& Shackleton, C.M. (2010), "Public green space inequality in small towns in South Africa.” Habitat International, 34(2), 244-48.

McGurn, W. \& Simon, J. (1990), “Little England's missed opportunity.” Economic Affairs, 10(5), 27-9.

Mehta, L. (2007), "Whose scarcity? Whose property? The case of water in western India." Land Use Policy, 24(4), 654-63.

Mellor, B. (1992), Lugard in Hong Kong: Empires, Education and a Governor at Work 1907 1912, Hong Kong University Press, Hong Kong.

Meskell, Y. (2002), "Negative heritage and past mastering in archaeology", Anthropological Quarterly, 75(3), 557-74.

Miners, N. (1975), The Government and Politics of Hong Kong, Oxford University Press, Hong Kong.

. (1987), Hong Kong under Imperial Rule, Oxford University Press, Hong Kong.

Morris, J. (1997), Hong Kong: Epilogue to an Empire, Penguin Books, Harmondsworth.

Munn, C. (2001), Anglo-China: Chinese People and British Rule in Hong Kong, 1841 1880. Curzon Press, Hong Kong.

Myrdal, G. (1944), An American Dilemma: The Negro Problem and Modern Democracy. Harper \& Row, New York.

Newby, R.G. (1982), "Segregation, desegregation and racial balance: status implications of these concepts.” The Urban Review, 14(1), 17-24.

Orenstein, D.E. \& Hamburg, S.P. (2009), “To populate or preserve? Evolving politicaldemographic and environmental paradigms in Israeli land-use policy." Land Use Policy, 26(4), 9841000.

Owen, N. \& Roberts, E. (1999), “The heritage of Hong Kong: history”, in Norman Owen; Elfed Roberts; David Lung; and Scarlet Cheng, The Heritage of Hong Kong: Its History, Architecture \& Culture, FormAsia, Hong Kong, 4-29. 
Pryor, E.G. (1983), Housing in Hong Kong, $2^{\text {nd }}$ edition, Oxford University Press, Hong Kong.

Roberts, J.P. and Situ, J.C.P. (2001), Valuation and Development land in Hong Kong, Empire Publications, Hong Kong.

Rosenthal, S.S. and Strange, W.C. (2003), "Geography, industrial organization, and agglomeration.” The Review of Economics and Statistics, 85(2), 377-93.

Sayer, G.R. (1975), Hong Kong 1862-1919, Hong Kong University Press, Hong Kong.

Shulman, F.J. and Shulman, A.L. (2001), Doctoral Dissertations on Hong Kong 1900 1977, Hong Kong University Press, Hong Kong.

Smith, C.T. (1995), A Sense of History Studies on the Social and Urban History of Hong Kong, Hong Kong Educational Publishing Co., Hong Kong.

Smith, J.S. (1993), Maltida: a Hong Kong Legacy, $2^{\text {nd }}$ edition. Hong Kong: Corporate Communications Ltd.

Stokes, G. (1965), Hong Kong in History, Hong Kong Government Printer, Hong Kong.

Swanwick, C. (2009), "Society's attitudes to and preferences for land and landscape." Land Use Policy, 26S, S62-S75.

Takaki, R. (2000), Double Victory: a Multicultural History of American World War II, Little Brown, Boston.

Ting, J.S.P. (1997), "Turning points in history: the formation and evolution of colonial institutions", in Chapter 3 in Gungwu Wang (ed.), Hong Kong History: New Perspectives Vol. 1., Joint Publishing Co. Ltd., Hong Kong, pp. 59-130 (Chinese publication).

Tsai, J.F. (1993), Hong Kong in Chinese History: Community and Social Unrest in the British Colony, 1842-1913, Columbia University Press, New York.

. (2001), The Hong Kong People's History of Hong Kong (1841-1945), Oxford University Press (China), Hong Kong (Chinese publication).

Uyanga, J. (1989), "Urban planning in Nigeria: Historical and administrative perspectives and a discussion of the city of Calabar,” Habitat International, 13(1), 121-42

Welsh, F. (1993), A History of Hong Kong, Harper Collins, London. 
Wesley-Smith, P. (1987), "Discriminatory legislation in Hong Kong”, draft of a paper presented at the academic symposium, The Historic Triangle of Britain, China and Hong Kong: a 60-year Retrospective 1927-1987, Lui Ming Chui Conference Centre, Hong Kong Baptist College, 11 June 1987.

. (1998), Unequal Treaty 1898-1997: China, Great Britain, and Hong Kong's New Territories, Oxford University Press, Hong Kong.

Wheeler, C.H. (2001), "Search, sorting, and urban agglomeration.” Journal of Labor Economics, 19(4), 879-99.

White, B. (1996), Hong Kong: Somewhere Between Heaven and Earth: An Anthology Selected and Edited by Barbara-Sue White, Oxford University Press, Hong Kong.

Wiltshire, T. (1995a), "The conflict of empires", in Old Hong Kong: Volume One 1860 1900, FormAsia, Hong Kong, 559.

Wiltshire, T. (1995), “The twilight of empire”, in Old Hong Kong: Volume Two 19011945, FormAsia, Hong Kong, 5-50.

Wood, F. (2000), No Dogs \& Not Many Chinese: Treaty Port Life in China 1943-1943, John Murray, London.

$\mathrm{Yu}$, B.T. (1981) "Potential Competition and Contracting in Innovation," Journal of Law and Economics, $24(2), 215-38$.

Yu, B.T., Shaw, D, Fu, T. and Lai, L.W.C. (2000), "A Property Rights and Contractual Approach to Sustainable Development," Environmental Economics and Policy Studies, 3(3), 291-309.

Yuan, D.Y. (1963), "Voluntary segregation: a study of new Chinatown." Phylon, 24(3,) $255-65$. 